SRNL-TR-2014-00170, Rev. 0

\title{
NINTH INTERIM STATUS REPORT: MODEL 9975 PCV O-RING FIXTURE LONG-TERM LEAK PERFORMANCE
}

\author{
W. L. Daugherty \\ Savannah River National Laboratory \\ Materials Science \& Technology
}

Publication Date: August 2014

Savannah River Nuclear Solutions

Savannah River Site

Aiken, SC 29808

This document was prepared in conjunction with work accomplished under

Contract No. DE-AC09-08SR22470 with the U.S. Department of Energy. 


\section{DISCLAIMER}

This work was prepared under an agreement with and funded by the U.S. Government. Neither the U. S. Government or its employees, nor any of its contractors, subcontractors or their employees, makes any express or implied: 1. warranty or assumes any legal liability for the accuracy, completeness, or for the use or results of such use of any information, product, or process disclosed; or 2. representation that such use or results of such use would not infringe privately owned rights; or 3. endorsement or recommendation of any specifically identified commercial product, process, or service. Any views and opinions of authors expressed in this work do not necessarily state or reflect those of the United States Government, or its contractors, or subcontractors. 


\section{Ninth Interim Status Report: Model 9975 PCV O-Ring Fixture Long-Term Leak Performance}

\section{APPROVALS:}

W. L. Daugherty

Date

Author, Materials Science and Technology

T. E. Skidmore

Date

Technical Review, Materials Science and Technology

K. A. Dunn

Date

Pu Surveillance Program Lead, Materials Science and Technology

G. T. Chandler

Date

Manager, Materials App \& Process Tech

E. R. Hackney

Date

NMM Engineering

\section{REVIEWS:}

D. R. Leduc

Date

Savannah River Packaging Technology 


\section{Revision Log}

Document No. SRNL-TR-2014-00170 Rev. No. 0

Document Title Ninth Interim Status Report: Model 9975 PCV O-Ring Fixture LongTerm Leak Performance

Rev. \# Page \# Description of Revision Date

$\begin{array}{llll}0 & \text { all Original document }\end{array}$ 


\section{Summary}

A series of experiments to monitor the aging performance of Viton ${ }^{\circledR}$ GLT O-rings used in the Model 9975 package has been ongoing since 2004 at the Savannah River National Laboratory. One approach has been to periodically evaluate the leak performance of O-rings being aged in mock-up 9975 Primary Containment Vessels (PCVs) at elevated temperatures. Other methods such as compression-stress relaxation (CSR) tests and field surveillance are also on-going to evaluate O-ring behavior. Seventy tests using PCV mock-ups were assembled and heated to temperatures ranging from 200 to $450{ }^{\circ} \mathrm{F}$. They were leak-tested initially and have been tested periodically to determine if they continue to meet the leak-tightness criterion defined in ANSI standard N14.5-97. Due to material substitution, fourteen additional tests were initiated in 2008 with GLT-S O-rings heated to temperatures ranging from 200 to $400{ }^{\circ} \mathrm{F}$.

High temperature aging continues for 23 GLT O-ring fixtures at $200-270{ }^{\circ} \mathrm{F}$. Room temperature leak test failures have been experienced in all of the GLT O-ring fixtures aging at $350{ }^{\circ} \mathrm{F}$ and higher temperatures, and in 8 fixtures aging at $300{ }^{\circ} \mathrm{F}$. The earliest $300{ }^{\circ} \mathrm{F}$ GLT Oring fixture failure was observed at 34 months. The remaining GLT O-ring fixtures aging at 300 ${ }^{\circ} \mathrm{F}$ have been retired from testing following more than 5 years at temperature without failure. No failures have yet been observed in GLT O-ring fixtures aging at $200{ }^{\circ} \mathrm{F}$ for 72 - 96 months, which bounds O-ring temperatures anticipated during storage in K-Area Complex (KAC). Based on expectations that the $200{ }^{\circ} \mathrm{F}$ fixtures will remain leak-tight for a significant period yet to come, 2 additional fixtures began aging in 2011 at $270{ }^{\circ} \mathrm{F}$, with hopes that they may reach a failure condition before the $200{ }^{\circ} \mathrm{F}$ fixtures, thus providing additional time to failure data.

High temperature aging continues for 6 GLT-S O-ring fixtures at $200-300{ }^{\circ} \mathrm{F}$. Room temperature leak test failures have been experienced in all 8 of the GLT-S O-ring fixtures aging at 350 and $400{ }^{\circ} \mathrm{F}$. No failures have yet been observed in GLT-S O-ring fixtures aging at 200 $300{ }^{\circ} \mathrm{F}$ for 54 - 57 months.

No additional O-ring failures have been observed since the last interim report was issued. Aging and periodic leak testing will continue for the remaining PCV fixtures. Additional irradiation of several fixtures is recommended to maintain a balance between thermal and radiation exposures similar to that experienced in storage, and to show the degree of consistency of radiation response between GLT and GLT-S O-rings.

\section{Background}

This is an interim status report for experiments carried out per Task Technical Plans WSRC-TR2003-00325 [1] and SRNS-TR-2008-00054 [2], which are part of the comprehensive 9975 package surveillance program [3].

PCV test fixtures were assembled with either Parker Seals V0835-75 (hereafter referred to as Viton ${ }^{\circledR}$ GLT) O-rings or Parker Seals VM835-75 (hereafter referred to as Viton ${ }^{\circledR}$ GLT-S) Orings, and are being aged in environments that provide varying degrees of margin over KAC storage conditions. The purpose of these experiments is to characterize the performance of the O-ring seals, and then correlate the data to lifetime predictions of PCV and SCV O-ring seals in 
9975 packages being stored in KAC. O-ring performance in these tests is defined by leaktightness, per ANSI standard N14.5-97 [4] at room temperature.

The data from these fixtures are scoping in nature, although most of the controls under which they were collected are typical of baseline data. Accordingly, care should be used to assess the overall quality of the data prior to use in baseline applications. Within the 9975 surveillance program, these data will be used for information only, to compare to baseline data from other testing and build confidence in the overall predictions of O-ring service life.

\section{Experimental Method}

\section{Test Matrix}

Testing has evolved to include 3 test matrices. These address Viton ${ }^{\circledR}$ GLT O-rings aged at 200 or $300{ }^{\circ} \mathrm{F}$, Viton ${ }^{\circledR}$ GLT O-rings aged at $270-450{ }^{\circ} \mathrm{F}$, and Viton ${ }^{\circledR}$ GLT-S O-rings aged at $200-$ $400{ }^{\circ} \mathrm{F}$.

The first test matrix was developed to determine the importance and effect of several variables on the condition of the PCV O-rings over time inside the KAC storage facility. The variables believed to be the most relevant to O-ring performance in storage were O-ring temperature, radiation/dose rate, O-ring lubrication, and internal PCV atmosphere (internal PCV atmosphere was subsequently dropped as a test variable). Two different dose rates were selected to evaluate potential dose rate effects. A total of 62 tests, with 22 separate sets of conditions were developed. Replicates of tests were developed based on a modified full-factorial statistical design. The test variables and the basis for variable selection are given in Table 1.

The interior of the test fixture is accessible through a tube connected to the bottom. This tube includes a $\mathrm{T}$ connection to facilitate leak testing of both O-rings simultaneously or separately. With this arrangement, data are obtained on both O-rings installed in each fixture. Although only the outer O-ring is credited for containment, testing both provides twice the information under nearly identical conditions.

Several fixtures have been removed from the first test matrix since the initiation of the study. Eleven were removed from test based on leak test performance while at their conditioning temperature of $200^{\circ} \mathrm{F}$ or $300^{\circ} \mathrm{F}$ and they were disassembled and examined. Fourteen more were taken out of test after a power failure caused a temperature excursion severe enough to invalidate the tests. One additional fixture was removed from test in 2007 for reasons that were not documented. Fixture 62 was returned to service briefly with new O-rings in 2007, and designated 62-2007. Further details of these fixtures are provided in Reference 5 . Several fixtures conditioning at $300{ }^{\circ} \mathrm{F}$ have experienced room temperature O-ring leakage (i.e. failed), beginning in April 2010. The status of each fixture, along with its test parameters, is summarized in Table 2.

Fixtures in the first test matrix were initially leak tested on a nominal 6-month schedule. Once the first of these began failing the room temperature leak test, the test frequency for fixtures heated to $300^{\circ} \mathrm{F}$ was increased to every 3 months. 
In the second test matrix, five fixtures were placed into test in October 2008 with new Viton ${ }^{\circledR}$ GLT O-rings. These fixtures were aged at temperatures ranging from 350 to $450{ }^{\circ} \mathrm{F}$. They were intended to provide some O-ring failures in a shorter time frame to enhance the predictive value of the original test matrix and to determine the time to failure at the vendor's service temperature rating $\left(400^{\circ} \mathrm{F}\right)$. The predictive model assumes that the time to leakage at all temperatures is a function of a common mechanism. With the expectation that these would fail in a much shorter time than the original fixtures, they were leak tested on a nominal 3 week frequency.

An additional two fixtures with Viton ${ }^{\circledR}$ GLT O-rings were added to the second test matrix in April 2011, and began aging at $270{ }^{\circ} \mathrm{F}$. With leak test failures experienced at aging temperatures of $300{ }^{\circ} \mathrm{F}$ and above, and no failures projected to occur at $200{ }^{\circ} \mathrm{F}$ for many years yet, it was anticipated that these two intermediate temperature fixtures might experience leak failures sooner that the $200{ }^{\circ} \mathrm{F}$ fixtures. This would provide additional confirmation of the extrapolation model for leak test data at an earlier date than the $200^{\circ} \mathrm{F}$ fixtures.

All of the second matrix fixtures were assembled with the normal O-ring lubricant and contained no backfill gas (i.e. filled with air). Three of them (one each at 350, 400 and $450{ }^{\circ} \mathrm{F}$ ) were irradiated to $2 \mathrm{E} 5 \mathrm{rad}$ at a high dose rate (approximating a 10-year service dose at a bounding rate of $2 \mathrm{rad} / \mathrm{hr})$.

The third test matrix repeats much of the variety of the first two matrices with Viton ${ }^{\circledR}$ GLT-S Orings, but on a smaller scale. Fewer fixtures were used for this alternate O-ring material since it is expected they will demonstrate the same parametric variations as the GLT O-rings. Seven separate sets of conditions were developed, and tested in duplicate for a total of 14 fixtures. The status of these fixtures, along with their test parameters, is summarized in Table 2.

\section{Initial Assembly and Setup}

The two-piece lid of the mock-up PCV, consisting of the cone seal nut and cone seal plug, was machined to be identical to the actual PCV lid. The body of the mock-up PCV was shortened to 3.5 inches from the original design of 18.6 inches and a threaded hole was machined in the bottom to provide a port for evacuating and filling the vessel with gas and for in-situ leak testing of the O-rings. A PCV test fixture with the O-rings installed in the lid is shown in Figure 1.

The mock-up PCV fixtures were assembled per the requirements described in the 9975 Safety Analysis Report for Packaging (SARP) [6]. After installation of the O-rings and assembly of the mock-up PCV test fixture, an initial leak test was performed while the fixture was at room temperature to verify leak-tightness to $1 \mathrm{E}-7 \mathrm{ref} \cdot \mathrm{cc} / \mathrm{sec}$ air or better. If the fixture required irradiation, it was placed in a Co-60 gamma cell and irradiated at one of two dose rates to reach a total dose of $2 \mathrm{E} 5 \mathrm{rad}$. This is equivalent to a ten year dose at the bounding dose rate expected for the PCV O-rings (2 rad/hr). The fixture was irradiated at either a "slow" dose rate of approximately 667 to $830 \mathrm{rad} / \mathrm{hr}$ (lasting approximately $240 \mathrm{hrs}$ ) or a faster rate of $\sim 1.7 \mathrm{E} 5 \mathrm{rad} / \mathrm{hr}$ (lasting 72 minutes), asViton ${ }^{\circledR}$ and other elastomers/polymers are known to be sensitive to the dose rate. After irradiation, the fixture was leak tested again while at room temperature to ensure that irradiation alone did not affect leak-tightness, and then heated to test temperature. 
The vessels are heated with a flexible, wound-wire heater wrapped around the vessel circumference. Ceramic fiberboard and fiber batting are used to insulate the exposed ends of the fixtures. Stainless steel tubing is attached to the port on the top of the fixture lid via a highpressure fitting and to the hole machined into the bottom of the PCV body. A thermal fuse was added to each heater to prevent excessive temperature excursions. The heaters are controlled by a desktop computer running LabView ${ }^{\mathrm{TM}}$ software, with feedback via a type-K thermocouple attached to the PCV body. The final assembled fixture is shown in Figure 2.

\section{Fixture Leak Testing}

The O-ring fixtures are leak-tested after initial setup, after irradiation, and periodically thereafter to the same leak-tight criterion as the 9975 PCV and SCV. The outer O-rings of the 9975 PCV and SCV are credited with being leak-tight while in transport and are credited with maintaining containment while in storage in the $\operatorname{KAC}[1,6]$.

A room temperature leakage rate of no more than $1 \mathrm{E}-7 \mathrm{ref} \cdot \mathrm{cc} / \mathrm{sec}$ air $(2 \mathrm{E}-7 \mathrm{cc} / \mathrm{sec} \mathrm{He})$ demonstrates leak-tightness when measured according to the requirements outlined in ANSI Standard N14.5-97 [4]. Initially, fixtures were also tested at their conditioning temperature. These additional tests were discontinued, as discussed previously [5].

Leak testing is conducted using a Varian 959 helium mass spectrometer leak detector. A gas filled envelope test, as defined in ANSI N14.5-97 Section A.5.3 is used for the mock-up PCV fixtures [4]. Both O-rings are tested simultaneously, with failure of either O-ring causing a failure of the test. Although this approach differs from annual certification testing, it gives results that are valid and comparable, and accommodates the difference in set up of the actual PCV and SCV and the mock-up PCV fixture. If a leak is found, it is possible to determine which O-ring is leaking by selectively directing the helium to either the fixture body or the closure weep hole, thus testing one O-ring at a time.

The O-ring fixture leak test program was reviewed in December 2008, prompting reconsideration of the methodology used for leak testing the mock-up PCV fixtures. One important change that was made in the conduct of the leak test involved extending the test duration until permeation of helium through the O-ring was detected [7].

Observing a permeation signal for each test provides positive evidence that the fixture and test setup are capable of transmitting a helium signal (i.e. no part of the flow path is blocked), and that helium was actually introduced into the fixture. Once a permeation signal was observed for each fixture (the permeation response is described in Reference 7), subsequent testing is conducted without the extended duration to demonstrate permeation, since no actions are performed that might disrupt the flow path during aging and leak testing. All fixtures in test since December 2008 have demonstrated permeation. The time to permeation ranged from 4-75 minutes? 


\section{$\underline{\text { Results }}$}

PCV fixtures have been assembled and aged to identify the time to failure of GLT O-rings (70 tests), and GLT-S O-rings (14 tests). This report summarizes results for these fixtures through July 10, 2014.

A total of 23 GLT O-ring fixtures and 6 GLT-S O-ring fixtures remain in test. All of the GLT O-ring fixtures conditioning at $200{ }^{\circ} \mathrm{F}$ have remained leak-tight at room temperature, with total times at temperature ranging from 72 to 96 months (at the time of their last leak test). Two fixtures began conditioning at $270{ }^{\circ} \mathrm{F}$ in 2011. They have remained leak-tight at room temperature, with total time at temperature of 35 months (at the time of their last leak test). Eight GLT fixtures conditioning at $300{ }^{\circ} \mathrm{F}$ were retired from test in July 2012 with exposure times ranging from 61 to 74 months. Each was given a final leak test, and permeation of helium through the O-rings was re-verified. In one of these fixtures (fixture 30) the inner O-ring had failed, but the outer O-ring remained leak-tight. Three of these fixtures were opened to examine the O-rings, while the remaining 5 fixtures are being maintained as-is for potential future test initiatives. GLT O-rings in the remaining fixtures aging at $300^{\circ} \mathrm{F}$ and higher failed previously, as noted in prior status reports. The times to failure for each GLT O-ring fixture are summarized in Table 3. Leak rate histories can be found in Table 4 for fixtures in test since the last status report [8].

All of the GLT-S O-ring fixtures conditioning at $200{ }^{\circ} \mathrm{F}, 250{ }^{\circ} \mathrm{F}$, and $300{ }^{\circ} \mathrm{F}$ have remained leaktight at room temperature, with total times at temperature of 54 to 57 months. GLT-S fixtures conditioned at $350{ }^{\circ} \mathrm{F}$ and at $400{ }^{\circ} \mathrm{F}$ failed as noted in previous status reports. The times to failure for each GLT-S O-ring fixture are summarized in Table 3. Detailed leak rate histories can be found in Table 4 for fixtures in test since the last status report [8].

Compression set values for all the opened fixtures have been calculated per ASTM D395 Method $\mathrm{B}$ and are summarized in Table 5.

\section{$\underline{\text { Discussion }}$}

As noted in the previous interim report [8], sufficient data are available to compare the time to failure for GLT and GLT-S O-rings at 3 temperatures. At $400{ }^{\circ} \mathrm{F}$, most of the GLT-S O-ring fixtures remained leak-tight longer than the GLT O-ring fixtures. At $350{ }^{\circ} \mathrm{F}$, the trend was reversed, with 3 of the 4 GLT O-rings in two fixtures remaining leak-tight longer than the GLT$\mathrm{S}$ O-ring fixtures. At $300{ }^{\circ} \mathrm{F}$, both GLT-S O-ring fixtures remain leak-tight after 45 months, while 5 GLT O-ring fixtures had failed by this time. With this varying trend, it is premature to conclude one material would perform better than the other, especially at the lower temperatures typical of storage service. This conclusion remains unchanged from the previous report since no additional leakage failures have occurred.

It is noted that GLT and GLT-S O-ring leak failures have occurred at $400{ }^{\circ} \mathrm{F}$ within 1 month and at $350^{\circ} \mathrm{F}$ within one year In addition, GLT O-ring leak failures have occurred at $300^{\circ} \mathrm{F}$ within 3 years. These temperatures are at or below the typical "maximum" service temperature often quoted for Viton/FKM-type fluoroelastomers $\left(40{ }^{\circ} \mathrm{F}\right)$. This highlights the limitation of such 
values for design purposes, as the time at temperature and failure criterion truly dictate service life.

A bounding steady state O-ring temperature of $199{ }^{\circ} \mathrm{F}$ has been calculated for an ambient temperature of $137^{\circ} \mathrm{F}$ and 19 watts payload [10]. Reference 11 reports the maximum ambient temperature actually recorded (at that time) was $104^{\circ} \mathrm{F}$, although temperatures are more typically $90{ }^{\circ} \mathrm{F}$ or less. For the more realistic bounding ambient temperature of $104^{\circ} \mathrm{F}$, the corresponding O-ring temperature would be expected to drop to $\sim 166{ }^{\circ} \mathrm{F}$. Lower internal heat loads and ambient temperatures more representative of typical storage conditions would lead to further reductions in the O-ring temperature. Even if bounding temperatures are reached, they are not sustained for chronic periods

The times at temperature for the fixtures to fail the room temperature leak test are shown graphically in Figure 3. In addition, the times at temperature for the fixtures still in test are also shown. A trend line is shown that provides a lower bound to the failure data to illustrate a potential extrapolation of the observed behavior to temperatures below $300{ }^{\circ} \mathrm{F}$, although the degree of scatter in the data would suggest significant uncertainty for extrapolations over a large temperature range. Nevertheless, this trend line suggests the possibility that O-rings aging at 200 ${ }^{\circ} \mathrm{F}$ might maintain a leak-tight seal for approximately 75 years, and O-rings at KAC storage temperatures have the potential for even greater service life.

The fixtures which were irradiated received a bounding 10 year dose (2E5 rads), based on the initial approved storage period. While thermal aging is expected to dominate O-ring behavior due to the low dose rates involved in service, the approved storage period has since been increased to 15 years, and further extensions are possible. In addition, there is an inherent imbalance between the bounding irradiation dose and the O-ring aging conditions. A bounding O-ring temperature of approximately $200^{\circ} \mathrm{F}$ was originally identified. Given that actual O-ring temperatures in storage are typically $\sim 166{ }^{\circ} \mathrm{F}$ or less, aging at $200{ }^{\circ} \mathrm{F}$ and above represents a significant acceleration of thermal aging. The aging model based on CSR data indicates O-ring degradation will occur $\sim 2.7$ times faster at $200{ }^{\circ} \mathrm{F}$ than at $166^{\circ} \mathrm{F}$, meaning that 8 years aging at $200{ }^{\circ} \mathrm{F}$ represents about 22 years aging at $166^{\circ} \mathrm{F}$. This same acceleration was not applied to the radiation dose. To maintain balance between these two degradation sources, it is recommended that some of the remaining fixtures which were initially irradiated receive further irradiation, as follows:

- 3 of the $200{ }^{\circ} \mathrm{F}$ fixtures should receive an additional 2 E5 rads (at the high dose rate) following their next scheduled leak test. At that time, they will have approximately 8 years aging time (at $200{ }^{\circ} \mathrm{F}$ ) which corresponds to approximately 22 years aging at $\sim 166^{\circ} \mathrm{F}$. These same 3 fixtures should continue to receive periodic irradiation to maintain this ratio of approximately $2 \mathrm{E} 5$ rads per 4 years at $200{ }^{\circ} \mathrm{F}$. These exposures do not ideally duplicate simultaneous radiation/thermal aging in service, but are intended to maintain a balance between degradation mechanisms.

- $\quad 3$ of the $200{ }^{\circ} \mathrm{F}$ fixtures should receive additional periodic irradiations to maintain a ratio of approximately half of the above bounding dose (1 E5 rads) per 4 years at $200{ }^{\circ} \mathrm{F}$, to provide a more realistic dose rate. The first of these irradiations would follow their next scheduled leak test. 
- 1 of the retired (but unopened) $300{ }^{\circ} \mathrm{F}$ fixtures should receive additional irradiation to a 50 year dose (1 E6 rads total), a 100 year dose (2 E6 rads total) and a 150 year dose (3 E6 rads total). 5 years aging at $300{ }^{\circ} \mathrm{F}$ corresponds to approximately 155 years aging at $166^{\circ} \mathrm{F}$. This fixture should be leak tested before each irradiation, and cycled to $300{ }^{\circ} \mathrm{F}$ and leak tested after each irradiation.

Each of the above irradiations will be performed on fixtures containing Viton GLT O-rings, since the GLT-S O-rings aging at these temperatures were not irradiated. This is mainly because at the time of GLT-S introduction into the test program, radiation was considered to be of less significance than thermal degradation. To better verify whether GLT-S O-rings respond comparably to GLT O-rings, the following steps are recommended:

- Install 2 GLT O-rings on a PCV lid ( 18\% stretch but no compression) and irradiate in incremental doses at the highest dose rate available until cracking is observed. Repeat with 2 GLT-S O-rings. Target doses have not been selected, but doses of 10, 50, 75, 100, 150 and 200 Mrad are suggested.

- Install 2 GLT O-rings on a PCV lid and torque onto a fixture ( $18 \%$ stretch plus compression) and irradiate to the dose identified above. Test if the fixture remains leaktight. If so, irradiate again to $2 \mathrm{x}, 5 \mathrm{x}$ and $10 \mathrm{x}$ the above dose, or until the fixture leaks (whichever comes first). Repeat for 2 GLT-S O-rings. These tests will not address possible variation in dose rate sensitivity between the two compounds, but such variation is expected to be minor based on similar polymer compositions.

\section{Conclusions}

High temperature aging continues for 23 GLT O-ring fixtures at $200-270{ }^{\circ} \mathrm{F}$. Room temperature leak test failures have been experienced by one or both O-rings in 8 of the GLT Oring fixtures aging at $300{ }^{\circ} \mathrm{F}$, and in all 5 of the GLT O-ring fixtures aging at higher temperatures. The remaining $8 \mathrm{GLT}$ O-ring fixtures aging at $300{ }^{\circ} \mathrm{F}$ were retired from testing following at least 61 months at temperature. No failures have yet been observed in GLT O-ring fixtures aging at $200{ }^{\circ} \mathrm{F}$ for 72 - 96 months, which is more representative of (but still bounding to) O-ring temperatures during storage in KAC. The maximum O-ring temperature expected in the $\mathrm{KAC}$ is $\sim 166^{\circ} \mathrm{F}$, based on a transient peak ambient temperature of $104^{\circ} \mathrm{F}$ and the maximum payload (19W). Average ambient temperatures and reduced payloads are less challenging to the seals in storage.

High temperature aging continues for 6 GLT-S O-ring fixtures at $200-300{ }^{\circ} \mathrm{F}$. Room temperature leak test failures have been experienced in all 8 of the GLT-S O-ring fixtures aging at 350 and $400{ }^{\circ} \mathrm{F}$. No failures have yet been observed in GLT-S O-ring fixtures aging at 200 $300{ }^{\circ} \mathrm{F}$ for $54-57$ months.

Aging and periodic leak testing will continue for the remaining fixtures. Additional irradiation of several fixtures is recommended to maintain a balance between thermal and radiation exposures similar to that experienced in storage, and to account for storage periods longer than the initial 10-year period. Tests are also recommended to show the degree of consistency of radiation response between GLT and GLT-S O-rings. 


\section{References}

[1] WSRC-TR-2003-00325, Rev. 4, “Task Technical and Quality Assurance Plan for Characterization and Surveillance of Model 9975 Package O-Rings and Celotex ${ }^{\circledR}$ Materials (U)”, January 2009.

[2] SRNS-TR-2008-00054, Rev. 0, “Task Technical and Quality Assurance Plan for Accelerated Aging of Viton ${ }^{\circledR}$ GLT-S O-rings for Model 9975 Shipping Packages in KAMS (U)”, January 2009.

[3] WSRC-TR-2001-0286, Rev. 4, "SRS Surveillance Program for Storage of Pu Material in KAMS”, July 2008.

[4] ANSI Standard N14.5-97, “American National Standard for Radioactive Materials Leakage Tests on Packages for Shipment”, American National Standards Institute, New York, NY, February 1998.

[5] SRNL-TR-2009-00186, "Fourth Interim Status Report: Model 9975 PCV O-Ring Fixture Long-Term Leak Performance”, W. L. Daugherty and T. M. Stefek, June 2009

[6] WSRC-SA-2002-00008, Rev. 0, “Safety Analysis Report for Packaging - Model 9975”, December 2003.

[7] SRNL-L1400-2008-00038, “Characterization of Leak Test System for O-Ring Studies”, D. J. Trapp, December 18, 2008.

[8] SRNL-TR-2013-00151, "Eighth Interim Status Report: Model 9975 PCV O-Ring Fixture Long-Term Leak Performance”, W. L. Daugherty, August 2013.

[9] SRNS-TR-2008-00290, Rev. 0, “Summary and Matrix 9975 Shipping Package Qualification Program for Extended Storage of Plutonium in the K Area Complex”, J. A. Radder, Savannah River Nuclear Solutions, Aiken, SC, November 2008.

[10] S-CLC-K-00194, Rev. 2, "Integrated Thermal Analysis of the 9975 Shipping Packages for KAMS Phase 6”, J. K. Norkus, March 16, 2011.

[11] OBU-NMM-2004-00060, “KAMS T-1 Temperature Readings”, S. M. Herlihy, March 25, 2004.

[12] L9.4-10500, Rev. 2, “Annual Maintenance and Leak Testing for the 9975 Shipping Package,” Instrumentation and Equipment Systems Section, SRNL, August 29, 2007. 
Table 1. Test Matrix Variables for O-Ring Experiment

\begin{tabular}{|c|c|c|}
\hline $\begin{array}{l}\text { Test } \\
\text { Variable }\end{array}$ & Values Tested & Basis for Values Tested \\
\hline \multirow[t]{3}{*}{ Temperature } & $\begin{array}{l}200^{\circ} \mathrm{F} \\
\left(93^{\circ} \mathrm{C}\right)\end{array}$ & $\begin{array}{l}\text { With loss of ventilation in the KAC facility, the } \\
\text { maximum ambient temperature is } 137{ }^{\circ} \mathrm{F} \text { [9], and the } \\
\text { corresponding PCV O-ring temperature is } 199^{\circ} \mathrm{F} \text { [10]. }\end{array}$ \\
\hline & $\begin{array}{l}300^{\circ} \mathrm{F} \\
\left(149^{\circ} \mathrm{C}\right)\end{array}$ & $\begin{array}{l}\text { The maximum allowable temperature for the PCV O- } \\
\text { rings for continuous operation is } 300^{\circ} \mathrm{F}[6] \text {. }\end{array}$ \\
\hline & $\begin{array}{l}270,350,400 \\
450^{\circ} \mathrm{F} \\
(132,177,204 \\
\left.232^{\circ} \mathrm{C}\right)\end{array}$ & $\begin{array}{l}\text { Elevated temperatures added to increase the likelihood } \\
\text { of seeing O-ring failures in shorter test periods. }\end{array}$ \\
\hline \multirow[t]{3}{*}{$\begin{array}{l}\text { Radiation } \\
\text { Dose }\end{array}$} & $\begin{array}{l}\text { 2E5 Rad in } 72 \\
\text { min }\end{array}$ & $\begin{array}{l}\text { The bounding (high) dose rate for the PCV is } 2 \mathrm{rad} / \mathrm{hr} \text {. } \\
\text { A total dose of } 2 \mathrm{E} 5 \mathrm{rad} \text { represents ten years of storage } \\
\text { (the initial period to be validated). }\end{array}$ \\
\hline & $\begin{array}{l}\text { 2E5 Rad in } \\
>200 \mathrm{hr}\end{array}$ & $\begin{array}{l}\text { Longer-term exposure may reveal the added effect of } \\
\text { diffusion-limited oxidation (DLO) that only occurs with } \\
\text { long-term exposure. (lower dose rate) }\end{array}$ \\
\hline & None & $\begin{array}{l}\text { Many packages will have little radiation exposure. This } \\
\text { also serves as an experimental control. }\end{array}$ \\
\hline \multirow[t]{3}{*}{$\begin{array}{l}\text { O-Ring } \\
\text { Lubrication }\end{array}$} & $\begin{array}{l}\text { Silicone high- } \\
\text { vacuum grease }\end{array}$ & It is specified in assembly of the 9975 package [12]. \\
\hline & Krytox® 240AC & $\begin{array}{l}\text { It has been used on } 9975 \text { O-rings at DOE facilities. It is } \\
\text { used on lid components of the } 9975 \text { PCV and SCV [12]. }\end{array}$ \\
\hline & None & $\begin{array}{l}\text { It supplies comparative control data. Also, it is possible } \\
\text { that the O-rings may be mistakenly installed without } \\
\text { grease. }\end{array}$ \\
\hline
\end{tabular}


Table 2. Summary of test parameters for fixtures

\begin{tabular}{|c|c|c|c|c|c|c|}
\hline \multirow[b]{2}{*}{$\begin{array}{l}\text { Temp. } \\
{ }^{\circ} \text { F }\end{array}$} & \multirow[b]{2}{*}{$\begin{array}{l}\text { Gamma } \\
\text { Dose (rad) / } \\
\text { Dose Rate }\end{array}$} & \multirow[b]{2}{*}{ Lubricant } & \multirow{2}{*}{$\begin{array}{l}\text { Fixtures Still in } \\
\text { Test }\end{array}$} & \multicolumn{3}{|c|}{ Fixtures Removed from Test } \\
\hline & & & & $\begin{array}{l}\text { Failed Leak } \\
\text { Test at } \\
\text { Room Temp }\end{array}$ & $\begin{array}{l}\text { Retired } \\
\text { July } \\
2012 \\
\end{array}$ & $\begin{array}{l}\text { For Other } \\
\text { Reasons }\end{array}$ \\
\hline \multicolumn{7}{|c|}{ GLT O-ring Fixtures - First Test Matrix } \\
\hline 200 & 2E5 High & Normal & $\begin{array}{l}5,6,9,27,36, \\
37,40,41,42, \\
53,54,55\end{array}$ & & & $15,16,23,24$ \\
\hline 200 & 2E5 Low & Normal & 10,11 & & & \\
\hline 200 & No & Normal & $\begin{array}{l}1,3,43,44 \\
56,57\end{array}$ & & & $13,28,29$ \\
\hline 300 & 2E5 High & Normal & & $8,12,26,31$ & $7,51,52$ & $\begin{array}{l}17,22,25,39, \\
45,46,47,58, \\
59,60\end{array}$ \\
\hline 300 & $\sim 2 \mathrm{E} 5$ Low & Normal & & 32 & $18,30 *$ & 21,38 \\
\hline 300 & No & Normal & & 49,33 & 4,61 & $\begin{array}{l}2,14,48,50, \\
62\end{array}$ \\
\hline 300 & $\sim 2 \mathrm{E} 5$ High & None & & & & 19 \\
\hline 300 & No & None & & & & 34 \\
\hline 200 & No & Krytox & 35 & & & \\
\hline 300 & $\sim 2 \mathrm{E} 5$ Low & Krytox & & & 20 & \\
\hline \multicolumn{7}{|c|}{ GLT O-ring Fixtures - Second Test Matrix } \\
\hline 270 & No & Normal & $14 \mathrm{~W}$ & & & \\
\hline 270 & No & Normal & 21W & & & \\
\hline 350 & $\sim 2 E 5$ High & Normal & & $18 \mathrm{D}$ & & \\
\hline 350 & No & Normal & & 19D & & \\
\hline 400 & $\sim 2 \mathrm{E} 5$ High & Normal & & 14D & & \\
\hline 400 & No & Normal & & $21 \mathrm{D}$ & & \\
\hline 450 & 2E5 High & Normal & & $23 \mathrm{D}$ & & \\
\hline \multicolumn{7}{|c|}{ GLT-S O-ring Fixtures - Third Test Matrix } \\
\hline 200 & None & Normal & $13 \mathrm{H}, 15 \mathrm{H}$ & & & \\
\hline 250 & None & Normal & $22 \mathrm{H}, 16 \mathrm{H}$ & & & \\
\hline 300 & None & Normal & $29 \mathrm{H}, 34 \mathrm{H}$ & & & \\
\hline 350 & None & Normal & & $38 \mathrm{H}, 39 \mathrm{H}$ & & \\
\hline 400 & None & Normal & & $45 \mathrm{H}, 58 \mathrm{H}$ & & \\
\hline 400 & None & Normal & & $60 \mathrm{H}, 62 \mathrm{H}$ & & \\
\hline 400 & 2E5 High & Normal & & $28 \mathrm{H}, 50 \mathrm{H}$ & & \\
\hline
\end{tabular}

* Fixture 30 has 1 failed O-ring (inner). 
Table 3. Summary of GLT and GLT-S O-ring leak failures

\begin{tabular}{|c|c|c|c|}
\hline & & \multicolumn{2}{|c|}{ Days at temperature to failure * } \\
\hline Fixture & $\begin{array}{c}\text { Temp } \\
\left({ }^{\circ} \mathrm{F}\right)\end{array}$ & Inner & Outer \\
\hline \multicolumn{4}{|c|}{ GLT O-ring Fixtures } \\
\hline 8 & 300 & $2009-2082$ & $2009-2082$ \\
\hline 12 & 300 & $957-1020$ & $957-1020$ \\
\hline 26 & 300 & $1273-1366$ & $1261-1273$ \\
\hline 30 & 300 & $1279-1392$ & 1902 - no fail \\
\hline 31 & 300 & $1280-1291$ & $1280-1291$ \\
\hline 32 & 300 & $1271-1352$ & $1271-1352$ \\
\hline 33 & 300 & $1360-1466$ & 1924 - 1979 \\
\hline 49 & 300 & $1101-1276$ & $1323-1360$ \\
\hline 18D & 350 & $481-497$ & $304-324$ \\
\hline 19D & 350 & $573-594$ & $560-571$ \\
\hline 14D & 400 & $29-45$ & $29-45$ \\
\hline $21 \mathrm{D}$ & 400 & $8-28$ & $8-28$ \\
\hline $23 \mathrm{D}$ & 450 & $10-12$ & $0-8$ \\
\hline \multicolumn{4}{|c|}{ GLT-S O-ring Fixtures } \\
\hline $38 \mathrm{H}$ & 350 & $338-358$ & $338-358$ \\
\hline $39 \mathrm{H}$ & 350 & $95-114$ & $95-114$ \\
\hline $45 \mathrm{H}$ & 400 & $65-99$ & $14-33$ \\
\hline $58 \mathrm{H}$ & 400 & $62-75$ & $62-75$ \\
\hline $60 \mathrm{H}$ & 400 & $33-50$ & $33-50$ \\
\hline $62 \mathrm{H}$ & 400 & $34-50$ & $34-50$ \\
\hline $28 \mathrm{H}$ & 400 & $33-50$ & $33-50$ \\
\hline $50 \mathrm{H}$ & 400 & $260-281$ & $260-281$ \\
\hline
\end{tabular}

* The first time at temperature is the last successful leak test. The second time at temperature is the failed leak test. Failure occurred at some point between these two times. 
Table 4. Room temperature leak rate data since 2011 (for fixtures in test since last status report)

\begin{tabular}{|l|l|l|}
\hline \multicolumn{2}{|l|}{ Test $1, \quad 200^{\circ} \mathrm{F}$} \\
\hline No rad. \\
\hline Date & $\begin{array}{l}\text { Time at Temp } \\
\text { (months) }\end{array}$ & $\begin{array}{l}\text { Leak Rate (std } \\
\text { cc He/sec) }\end{array}$ \\
\hline $3 / 15 / 2011$ & 60 & $<3.0$ E-8 \\
\hline $9 / 19 / 2011$ & 66 & $<3.0$ E-8 \\
\hline $3 / 19 / 2012$ & 72 & $<2.0$ E-9 \\
\hline $10 / 8 / 2012$ & 78 & 1.3 E-8 \\
\hline $7 / 9 / 2013$ & 85 & 5.3 E-9 \\
\hline $12 / 3 / 13$ & 90 & 1.3 E-8 \\
\hline $6 / 10 / 14$ & 96 & 2.4 E-8 \\
\hline
\end{tabular}

\begin{tabular}{|l|l|l|}
\hline \multicolumn{2}{|l|}{ Test 3, $200^{\circ} \mathrm{F}$} \\
\hline No rad. & $\begin{array}{l}\text { Time at Temp } \\
(\text { months) }\end{array}$ & $\begin{array}{l}\text { Leak Rate (std } \\
\text { cc He/sec) }\end{array}$ \\
\hline Date & 59 & $<2.8 \mathrm{E}-8$ \\
\hline $2 / 1 / 2011$ & 65 & $<1.8 \mathrm{E}-8$ \\
\hline $8 / 1 / 2011$ & 72 & $<1.6 \mathrm{E}-8$ \\
\hline $2 / 22 / 2012$ & 72 & $<1.0 \mathrm{E}-8$ \\
\hline $9 / 5 / 2012$ & 80 & $5.9 \mathrm{E}-9$ \\
\hline $5 / 14 / 2013$ & 84 & $5.8 \mathrm{E}-9$ \\
\hline $11 / 12 / 13$ & 90 & $1.3 \mathrm{E}-8$ \\
\hline $5 / 13 / 14$ & 96 & \\
\hline
\end{tabular}

\begin{tabular}{|l|l|l|}
\hline \multicolumn{3}{|l|}{ Test 5, $200{ }^{\circ} \mathrm{F}$} \\
\hline 2E5Rad /72 $\min$ \\
\hline Date & $\begin{array}{l}\text { Time at Temp } \\
\text { (months) }\end{array}$ & $\begin{array}{l}\text { Leak Rate (std } \\
\text { cc He/sec) }\end{array}$ \\
\hline $3 / 14 / 2011$ & 59 & $<2.4$ E-8 \\
\hline $10 / 24 / 2011$ & 66 & $<2.6$ E-8 \\
\hline $4 / 30 / 2012$ & 71 & 1.0 E-7 \\
\hline $11 / 15 / 2012$ & 78 & $<1.6$ E-9 \\
\hline $7 / 25 / 13$ & 84 & 8.7 E-9 \\
\hline $1 / 22 / 14$ & 90 & 2.7 E-8 \\
\hline & & \\
\hline
\end{tabular}

\begin{tabular}{|l|l|l|}
\hline \multicolumn{3}{|l|}{ Test 6, $200{ }^{\circ} \mathrm{F}$} \\
\hline 2E5Rad $/ 72$ min \\
\hline Date & $\begin{array}{l}\text { Time at Temp } \\
\text { (months) }\end{array}$ & $\begin{array}{l}\text { Leak Rate (std } \\
\text { cc He/sec) }\end{array}$ \\
\hline $3 / 14 / 2011$ & 59 & $<2.0 \mathrm{E}-8$ \\
\hline $10 / 24 / 2011$ & 66 & $<2.8 \mathrm{E}-8$ \\
\hline $5 / 1 / 2012$ & 72 & $<3.4 \mathrm{E}-8$ \\
\hline $11 / 15 / 2012$ & 78 & $9.1 \mathrm{E}-9$ \\
\hline $7 / 9 / 2013$ & 84 & $1.5 \mathrm{E}-8$ \\
\hline $1 / 7 / 14$ & 90 & $<2.5 \mathrm{E}-9$ \\
\hline $7 / 8 / 14$ & 96 & $3.8 \mathrm{E}-8$ \\
\hline
\end{tabular}

\begin{tabular}{|l|l|l|}
\hline \multicolumn{3}{|l|}{ Test 9, $200^{\circ} \mathrm{F}$} \\
\hline 2E5Rad $/ 72$ min \\
\hline Date & $\begin{array}{l}\text { Time at Temp } \\
\text { (months) }\end{array}$ & $\begin{array}{l}\text { Leak Rate (std } \\
\text { cc He/sec) }\end{array}$ \\
\hline $6 / 27 / 2011$ & 53 & 2.6 E-8 \\
\hline $1 / 24 / 2012$ & 59 & 2.4 E-9 \\
\hline $8 / 15 / 2012$ & 66 & $<1.2$ E-8 \\
\hline $4 / 9 / 2013$ & 72 & $<2.4$ E-9 \\
\hline $10 / 8 / 13$ & 78 & 2.8 E-9 \\
\hline $4 / 8 / 14$ & 84 & 6.0 E-9 \\
\hline & & \\
\hline
\end{tabular}

\begin{tabular}{|l|l|l|}
\hline \multicolumn{3}{|l|}{ Test 10, $200^{\circ} \mathrm{F}$} \\
\hline 2E5Rad /240 hr \\
\hline Date & $\begin{array}{l}\text { Time at Temp } \\
\text { (months) }\end{array}$ & $\begin{array}{l}\text { Leak Rate (std } \\
\text { Cc He/sec) }\end{array}$ \\
\hline $2 / 15 / 2011$ & 54 & $<2.2$ E-8 \\
\hline $8 / 16 / 2011$ & 60 & $<4.0$ E-9 \\
\hline $2 / 22 / 2012$ & 66 & $<2.0$ E-8 \\
\hline $9 / 10 / 2012$ & 72 & 1.6 E-8 \\
\hline $5 / 14 / 2013$ & 78 & $<1.7$ E-9 \\
\hline $11 / 12 / 13$ & 84 & 1.2 E-9 \\
\hline $5 / 13 / 14$ & 90 & 8.6 E-9 \\
\hline
\end{tabular}

\begin{tabular}{|l|l|l|}
\hline \multicolumn{3}{|l|}{ Test 11, $200^{\circ} \mathrm{F}$} \\
\hline 1.4E5 Rad /479 hr \\
\hline Date & $\begin{array}{l}\text { Time at Temp } \\
\text { (months) }\end{array}$ & $\begin{array}{l}\text { Leak Rate (std } \\
\text { cc He/sec) }\end{array}$ \\
\hline $2 / 15 / 2011$ & 54 & $<2.6$ E-8 \\
\hline $8 / 16 / 2011$ & 59 & 2.7 E-7 \\
\hline $3 / 19 / 2012$ & 66 & $<2.4$ E-8 \\
\hline $10 / 8 / 2012$ & 72 & 2.7 E-9 \\
\hline $6 / 4 / 2013$ & 78 & 5.5 E-9 \\
\hline $12 / 3 / 13$ & 84 & 7.8 E-9 \\
\hline $5 / 3 / 14$ & 89 & 8.6 E-9 \\
\hline
\end{tabular}

\begin{tabular}{|l|l|l|}
\hline \multicolumn{3}{|l|}{ Test 27, $200{ }^{\circ} \mathrm{F}$} \\
\hline 2E5Rad $/ 72$ min \\
\hline Date & $\begin{array}{l}\text { Time at Temp } \\
\text { (months) }\end{array}$ & $\begin{array}{l}\text { Leak Rate (std } \\
\text { cc He/sec) }\end{array}$ \\
\hline $3 / 15 / 2011$ & 41 & $<1.6$ E-8 \\
\hline $10 / 24 / 2011$ & 48 & $<2.6$ E-8 \\
\hline $5 / 30 / 2012$ & 54 & $<2.8$ E-8 \\
\hline $12 / 11 / 2012$ & 61 & 5.8 E-9 \\
\hline $8 / 13 / 13$ & 67 & 8.2 E-9 \\
\hline $1 / 22 / 14$ & 72 & 5.4 E-9 \\
\hline & & \\
\hline
\end{tabular}

* Test 11 - failed bag test at 59 months. Each O-ring ok individually. 
Table 4. (cont) Room temperature leak rate data since 2011 (for fixtures in test since last status report)

\begin{tabular}{|l|l|l|}
\hline \multicolumn{2}{|l|}{ Test 35, $200^{\circ} \mathrm{F}$} \\
\hline No rad. \\
\hline Date & $\begin{array}{l}\text { Time at Temp } \\
\text { (months) }\end{array}$ & $\begin{array}{l}\text { Leak Rate (std } \\
\text { cc He/sec) }\end{array}$ \\
\hline $3 / 15 / 2011$ & 54 & $<1.8$ E-8 \\
\hline $10 / 24 / 2011$ & 60 & $<2.6$ E-8 \\
\hline $4 / 30 / 2012$ & 66 & $<2.6$ E-8 \\
\hline $11 / 15 / 2012$ & 73 & $<1.6$ E-9 \\
\hline $7 / 9 / 2013$ & 78 & 1.7 E-8 \\
\hline $1 / 7 / 14$ & 84 & 9.8 E-8 \\
\hline $7 / 8 / 14$ & 90 & 3.8 E-8 \\
\hline
\end{tabular}

\begin{tabular}{|l|l|l|}
\hline \multicolumn{3}{|l|}{ Test 36, $200^{\circ} \mathrm{F}$} \\
\hline 2E5Rad $/ 72 \mathrm{~min}$ \\
\hline Date & $\begin{array}{l}\text { Time at Temp } \\
\text { (months) }\end{array}$ & $\begin{array}{l}\text { Leak Rate (std } \\
\text { cc He/sec) }\end{array}$ \\
\hline $2 / 15 / 2011$ & 53 & $<3.2 \mathrm{E}-8$ \\
\hline $8 / 16 / 2011$ & 60 & $<6.0$ E-9 \\
\hline $3 / 19 / 2012$ & 66 & $<2.2$ E-8 \\
\hline $10 / 8 / 2012$ & 72 & $<1.9$ E-9 \\
\hline $6 / 4 / 2013$ & 78 & $<1.9$ E-9 \\
\hline $12 / 2 / 13$ & 84 & 7.8 E-9 \\
\hline $6 / 10 / 14$ & 90 & 3.3 E-9 \\
\hline
\end{tabular}

\begin{tabular}{|l|l|l|}
\hline \multicolumn{3}{|l|}{ Test 37, $200^{\circ} \mathrm{F}$} \\
\hline 2E5Rad $/ 72$ min \\
\hline Date & $\begin{array}{l}\text { Time at Temp } \\
\text { (months) }\end{array}$ & $\begin{array}{l}\text { Leak Rate }(\text { std } \\
\text { cc He/sec) }\end{array}$ \\
\hline $2 / 15 / 2011$ & 53 & $<3.6$ E-8 \\
\hline $8 / 16 / 2011$ & 60 & $<6.0$ E-9 \\
\hline $3 / 19 / 2012$ & 66 & $<2.0$ E-8 \\
\hline $10 / 8 / 2012$ & 72 & 2.7 E-8 \\
\hline $6 / 4 / 2013$ & 78 & $<1.9$ E-9 \\
\hline $12 / 3 / 13$ & 84 & 2.6 E-9 \\
\hline $6 / 10 / 14$ & 90 & 4.3 E-8 \\
\hline
\end{tabular}

\begin{tabular}{|l|l|l|}
\hline \multicolumn{3}{|l|}{ Test 40, $200^{\circ} \mathrm{F}$} \\
\hline 2E5Rad $/ 72$ min \\
\hline Date & $\begin{array}{l}\text { Time at Temp } \\
\text { (months) }\end{array}$ & $\begin{array}{l}\text { Leak Rate (std } \\
\text { cc He/sec) }\end{array}$ \\
\hline $6 / 27 / 2011$ & 53 & $<1.2 \mathrm{E}-8$ \\
\hline $1 / 24 / 2012$ & 60 & $<3.4 \mathrm{E}-8$ \\
\hline $8 / 15 / 2012$ & 66 & $<1.4 \mathrm{E}-8$ \\
\hline $4 / 9 / 2013$ & 72 & $2.2 \mathrm{E}-9$ \\
\hline $10 / 8 / 13$ & 78 & $2.8 \mathrm{E}-9$ \\
\hline $4 / 8 / 14$ & 84 & $1.8 \mathrm{E}-8$ \\
\hline & & \\
\hline
\end{tabular}

\begin{tabular}{|l|l|l|}
\hline \multicolumn{3}{|l|}{ Test 41, $200^{\circ} \mathrm{F}$} \\
\hline 2E5Rad $/ 72$ min \\
\hline Date & $\begin{array}{l}\text { Time at Temp } \\
\text { (months) }\end{array}$ & $\begin{array}{l}\text { Leak Rate }(\text { std } \\
\text { cc He/sec) }\end{array}$ \\
\hline $2 / 1 / 2011$ & 53 & $<3.4$ E-8 \\
\hline $8 / 1 / 2011$ & 59 & $<1.4$ E-8 \\
\hline $2 / 22 / 2012$ & 65 & $<2.6$ E-8 \\
\hline $9 / 10 / 2012$ & 72 & $<1.6$ E-8 \\
\hline $5 / 14 / 2013$ & 78 & $<1.7$ E-9 \\
\hline $11 / 12 / 13$ & 84 & $<2.9$ E-9 \\
\hline $5 / 13 / 14$ & 90 & 3.9 E-9 \\
\hline
\end{tabular}

\begin{tabular}{|l|l|l|}
\hline \multicolumn{3}{|l|}{ Test 42, $200^{\circ} \mathrm{F}$} \\
\hline 2E5Rad $/ 72 \mathrm{~min}$ \\
\hline Date & $\begin{array}{l}\text { Time at Temp } \\
\text { (months) }\end{array}$ & $\begin{array}{l}\text { Leak Rate (std } \\
\text { cc He/sec) }\end{array}$ \\
\hline $2 / 1 / 2011$ & 53 & $<2.8 \mathrm{E}-8$ \\
\hline $8 / 1 / 2011$ & 60 & $<1.2 \mathrm{E}-8$ \\
\hline $2 / 22 / 2012$ & 65 & $<1.6 \mathrm{E}-8$ \\
\hline $9 / 6 / 2012$ & 72 & $<1.2 \mathrm{E}-8$ \\
\hline $5 / 14 / 2013$ & 78 & $7.1 \mathrm{E}-9$ \\
\hline $11 / 13 / 13$ & 84 & $1.7 \mathrm{E}-8$ \\
\hline $5 / 13 / 14$ & 90 & $2.9 \mathrm{E}-8$ \\
\hline
\end{tabular}

\begin{tabular}{|l|l|l|}
\hline \multicolumn{3}{|l|}{ Test 43, $200^{\circ} \mathrm{F}$} \\
\hline No rad. & $\begin{array}{l}\text { Time at Temp } \\
\text { (months) }\end{array}$ & $\begin{array}{l}\text { Leak Rate (std } \\
\text { cc He/sec) }\end{array}$ \\
\hline Date & 53 & $<3.6$ E-8 \\
\hline $2 / 15 / 2011$ & 59 & $<4.0$ E-9 \\
\hline $8 / 16 / 2011$ & 59 & $<9.8$ E-10 \\
\hline $3 / 19 / 2012$ & 66 & 2.7 E-9 \\
\hline $10 / 8 / 2012$ & 72 & $<1.9$ E-9 \\
\hline $6 / 4 / 2013$ & 78 & 1.6 E-8 \\
\hline $12 / 3 / 13$ & 84 & 6.4 E-9 \\
\hline $6 / 18 / 14$ & 90 &
\end{tabular}

\begin{tabular}{|l|l|l|}
\hline \multicolumn{3}{|l|}{ Test 44, $200^{\circ} \mathrm{F}$} \\
\hline No rad. & $\begin{array}{l}\text { Time at Temp } \\
\text { (months) }\end{array}$ & $\begin{array}{l}\text { Leak Rate (std } \\
\text { cc He/sec) }\end{array}$ \\
\hline Date & 54 & $<2.4 \mathrm{E}-8$ \\
\hline $2 / 1 / 2011$ & 60 & $<1.4 \mathrm{E}-8$ \\
\hline $8 / 1 / 2011$ & 66 & $<2.0 \mathrm{E}-8$ \\
\hline $2 / 22 / 2012$ & 72 & $<1.0 \mathrm{E}-8$ \\
\hline $9 / 6 / 2012$ & 72 & $<1.7 \mathrm{E}-9$ \\
\hline $5 / 14 / 2013$ & 78 & $5.8 \mathrm{E}-9$ \\
\hline $11 / 12 / 13$ & 84 & $1.2 \mathrm{E}-8$ \\
\hline $5 / 13 / 14$ & 90 & \\
\hline
\end{tabular}


Table 4. (cont) Room temperature leak rate data since 2011 (for fixtures in test since last status report)

\begin{tabular}{|l|l|l|}
\hline \multicolumn{3}{|l|}{ Test 53, $200^{\circ} \mathrm{F}$} \\
\hline 2E5Rad $/ 72 \mathrm{~min}$ \\
\hline Date & $\begin{array}{l}\text { Time at Temp } \\
\text { (months) }\end{array}$ & $\begin{array}{l}\text { Leak Rate }(\text { std } \\
\text { Cc He/sec) }\end{array}$ \\
\hline $2 / 1 / 2011$ & 54 & $<3.2$ E-8 \\
\hline $8 / 1 / 2011$ & 60 & $<3.6$ E-8 \\
\hline $2 / 22 / 2012$ & 66 & $<2.0$ E-8 \\
\hline $9 / 10 / 2012$ & 72 & $<2.2$ E-8 \\
\hline $5 / 14 / 2013$ & 78 & 1.2 E-8 \\
\hline $11 / 12 / 13$ & 84 & $<2.0$ E-9 \\
\hline $5 / 13 / 14$ & 90 & 5.5 E-8 \\
\hline
\end{tabular}

\begin{tabular}{|l|l|l|}
\hline \multicolumn{3}{|l|}{ Test 54, $200^{\circ} \mathrm{F}$} \\
\hline 2E5Rad $/ 72$ min \\
\hline Date & $\begin{array}{l}\text { Time at Temp } \\
\text { (months) }\end{array}$ & $\begin{array}{l}\text { Leak Rate (std } \\
\text { cc He/sec) }\end{array}$ \\
\hline $2 / 1 / 2011$ & 54 & $<1.8 \mathrm{E}-8$ \\
\hline $8 / 1 / 2011$ & 59 & $<2.6 \mathrm{E}-8$ \\
\hline $2 / 22 / 2012$ & 66 & $<1.9 \mathrm{E}-8$ \\
\hline $9 / 10 / 2012$ & 72 & $<2.0 \mathrm{E}-8$ \\
\hline $5 / 14 / 2013$ & 78 & $1.2 \mathrm{E}-8$ \\
\hline $11 / 12 / 13$ & 84 & $<2.0 \mathrm{E}-9$ \\
\hline $5 / 13 / 14$ & 90 & $<2.7 \mathrm{E}-9$ \\
\hline
\end{tabular}

\begin{tabular}{|l|l|l|}
\hline \multicolumn{3}{|l|}{ Test 55, $200^{\circ} \mathrm{F}$} \\
\hline 2E5Rad $/ 72$ min \\
\hline Date & $\begin{array}{l}\text { Time at Temp } \\
\text { (months) }\end{array}$ & $\begin{array}{l}\text { Leak Rate }(\text { std } \\
\text { cc He/sec) }\end{array}$ \\
\hline $2 / 1 / 2011$ & 53 & $<3.0$ E-8 \\
\hline $8 / 1 / 2011$ & 59 & $<1.0$ E-8 \\
\hline $2 / 22 / 2012$ & 65 & $<1.6$ E-8 \\
\hline $9 / 10 / 2012$ & 72 & $<1.6$ E-8 \\
\hline $5 / 14 / 2013$ & 78 & 2.4 E-9 \\
\hline $11 / 12 / 13$ & 84 & 2.9 E-9 \\
\hline $5 / 13 / 14$ & 90 & 4.0 E-8 \\
\hline
\end{tabular}

\begin{tabular}{|l|l|l|}
\hline \multicolumn{3}{|l|}{ Test 56, $200^{\circ} \mathrm{F}$} \\
\hline No rad. & $\begin{array}{l}\text { Time at Temp } \\
\text { (months) }\end{array}$ & $\begin{array}{l}\text { Leak Rate (std } \\
\text { cc He/sec) }\end{array}$ \\
\hline Date & 53 & $<2.2 \mathrm{E}-8$ \\
\hline $3 / 15 / 2011$ & $<3.2 \mathrm{E}-8$ \\
\hline $10 / 24 / 2011$ & 60 & $<1.8 \mathrm{E}-8$ \\
\hline $4 / 30 / 2012$ & 66 & $<1.6 \mathrm{E}-9$ \\
\hline $11 / 15 / 2012$ & 72 & $1.1 \mathrm{E}-8$ \\
\hline $7 / 9 / 2013$ & 78 & $7.4 \mathrm{E}-8$ \\
\hline $1 / 7 / 14$ & 84 & $1.6 \mathrm{E}-8$ \\
\hline $7 / 8 / 14$ & 90 & \\
\hline
\end{tabular}

\begin{tabular}{|l|l|l|}
\hline \multicolumn{2}{|l|}{ Test 57, $200{ }^{\circ} \mathrm{F}$} \\
\hline No rad. \\
\hline Date & $\begin{array}{l}\text { Time at Temp } \\
\text { (months) }\end{array}$ & $\begin{array}{l}\text { Leak Rate (std } \\
\text { cc He/sec) }\end{array}$ \\
\hline $2 / 15 / 2011$ & 53 & $<2.6$ E-8 \\
\hline $8 / 16 / 2011$ & 59 & $<6.0$ E-9 \\
\hline $3 / 20 / 2012$ & 66 & $<1.8$ E-8 \\
\hline $10 / 8 / 2012$ & 72 & $<1.9$ E-9 \\
\hline $6 / 4 / 2013$ & 78 & 2.8 E-9 \\
\hline $12 / 3 / 13$ & 84 & 2.6 E-9 \\
\hline $6 / 18 / 14$ & 90 & 1.0 E-8 \\
\hline
\end{tabular}

\begin{tabular}{|l|l|l|}
\hline \multicolumn{3}{|l|}{ Test $14 \mathrm{~W}, 270^{\circ} \mathrm{F}$} \\
\hline No rad. & $\begin{array}{l}\text { Time at Temp } \\
\text { (months) }\end{array}$ & $\begin{array}{l}\text { Leak Rate (std } \\
\text { cc He/sec) }\end{array}$ \\
\hline Date & Baseline & $<1.6$ E-8 \\
\hline $4 / 18 / 2011$ & 5 & $<2.6$ E-8 \\
\hline $10 / 24 / 2011$ & 5 & $<2.8$ E-8 \\
\hline $5 / 30 / 2012$ & 12 & 8.2 E-9 \\
\hline $8 / 13 / 13$ & 25 & 1.2 E-7 \\
\hline $7 / 9 / 14$ & 35 & \\
\hline & & \\
\hline & & \\
\hline
\end{tabular}

\begin{tabular}{|l|l|l|}
\hline \multicolumn{2}{|l|}{ Test 21W, $270^{\circ} \mathrm{F}$} \\
\hline No rad. & $\begin{array}{l}\text { Time at Temp } \\
\text { (months) }\end{array}$ & $\begin{array}{l}\text { Leak Rate (std } \\
\text { cc He/sec) }\end{array}$ \\
\hline Date & Baseline & $<1.6$ E-8 \\
\hline $4 / 18 / 2011$ & $<2.4$ E-8 \\
\hline $10 / 24 / 2011$ & 6 & $<3.0$ E-8 \\
\hline $5 / 30 / 2012$ & 12 & 5.5 E-9 \\
\hline $8 / 13 / 13$ & 25 & 1.6 E-8 \\
\hline $7 / 8 / 14$ & 35 &
\end{tabular}


Table 4. (cont) Room temperature leak rate data since 2011 (for fixtures in test since last status report)

\begin{tabular}{|l|l|l|}
\hline \multicolumn{2}{|l|}{ Test $13 \mathrm{H}$ (GLT-S), $200^{\circ} \mathrm{F}$} \\
\hline No rad. \\
\hline Date & $\begin{array}{l}\text { Time at Temp } \\
\text { (months) }\end{array}$ & $\begin{array}{l}\text { Leak Rate (std } \\
\text { cc He/sec) }\end{array}$ \\
\hline $6 / 27 / 2011$ & 25 & $<1.6$ E-8 \\
\hline $11 / 28 / 2011$ & 30 & $<1.8$ E-8 \\
\hline $5 / 29 / 2012$ & 35 & $<3.8$ E-8 \\
\hline $12 / 11 / 2012$ & 42 & 5.8 E-9 \\
\hline $8 / 13 / 13$ & 48 & $<1.9$ E-9 \\
\hline $2 / 20 / 14$ & 54 & 1.6 E-8 \\
\hline
\end{tabular}

\begin{tabular}{|l|l|l|}
\hline \multicolumn{3}{|l|}{ Test $15 \mathrm{H}$ (GLT-S), $200^{\circ} \mathrm{F}$} \\
\hline No rad. & $\begin{array}{l}\text { Time at Temp } \\
\text { (months) }\end{array}$ & $\begin{array}{l}\text { Leak Rate (std } \\
\text { cc He/sec) }\end{array}$ \\
\hline Date & 26 & $<1.0$ E-8 \\
\hline $6 / 27 / 2011$ & 30 & $<1.6$ E-8 \\
\hline $11 / 28 / 2011$ & 30 & $<4.2$ E-8 \\
\hline $5 / 29 / 2012$ & 36 & 5.8 E-9 \\
\hline $12 / 11 / 2012$ & 42 & 5.5 E-9 \\
\hline $8 / 13 / 13$ & 48 & $<1.9$ E-9 \\
\hline $1 / 22 / 14$ & 54 &
\end{tabular}

\begin{tabular}{|l|l|l|}
\hline \multicolumn{3}{|l|}{ Test $16 \mathrm{H}$ (GLT-S), $250^{\circ} \mathrm{F}$} \\
\hline No rad.. \\
\hline Date & $\begin{array}{l}\text { Time at Temp } \\
\text { (months) }\end{array}$ & $\begin{array}{l}\text { Leak Rate (std } \\
\text { cc He/sec) }\end{array}$ \\
\hline $6 / 27 / 2011$ & 22 & $<1.8$ E-8 \\
\hline $3 / 20 / 2012$ & 30 & 1.6 E-8 \\
\hline $10 / 8 / 2012$ & 36 & 1.3 E-8 \\
\hline $6 / 4 / 2013$ & 41 & $<1.9$ E-9 \\
\hline $12 / 3 / 13$ & 48 & 7.8 E-9 \\
\hline $6 / 10 / 14$ & 54 & 3.3 E-9 \\
\hline
\end{tabular}

\begin{tabular}{|l|l|l|}
\hline \multicolumn{3}{|l|}{ Test 22H (GLT-S), $250{ }^{\circ} \mathrm{F}$} \\
\hline No rad. & $\begin{array}{l}\text { Time at Temp } \\
\text { (months) }\end{array}$ & $\begin{array}{l}\text { Leak Rate (std } \\
\text { cc He/sec) }\end{array}$ \\
\hline Date & 24 & $<1.4$ E-8 \\
\hline $6 / 27 / 2011$ & 30 & $<2.6$ E-8 \\
\hline $1 / 24 / 2012$ & 37 & $<1.1 \mathrm{E}-8$ \\
\hline $8 / 15 / 2012$ & 37 & $5.4 \mathrm{E}-8$ \\
\hline $4 / 9 / 2013$ & 42 & $1.1 \mathrm{E}-8$ \\
\hline $10 / 8 / 13$ & 48 & $9.0 \mathrm{E}-9$ \\
\hline $4 / 8 / 14$ & 54 & \\
\hline
\end{tabular}

\begin{tabular}{|l|l|l|}
\hline \multicolumn{2}{|l|}{ Test 29H (GLT-S), $300^{\circ} \mathrm{F}$} \\
\hline No rad. \\
\hline Date & $\begin{array}{l}\text { Time at Temp } \\
\text { (months) }\end{array}$ & $\begin{array}{l}\text { Leak Rate } \text { (std } \\
\text { cc He/sec) }\end{array}$ \\
\hline $3 / 15 / 2011$ & 20 & $<2.6$ E-8 \\
\hline $6 / 8 / 2011$ & 23 & $<2.4$ E-8 \\
\hline $10 / 18 / 2011$ & 27 & 3.9 E-8 \\
\hline $1 / 10 / 2012$ & 30 & $<2.8$ E-8 \\
\hline $4 / 30 / 2012$ & 33 & 3.4 E-8 \\
\hline $8 / 15 / 2012$ & 36 & $<1.1$ E-8 \\
\hline $11 / 15 / 2012$ & 39 & 9.1 E-9 \\
\hline $4 / 9 / 2013$ & 42 & 9.9 E-9 \\
\hline $7 / 9 / 2013$ & 45 & 1.3 E-8 \\
\hline $10 / 8 / 13$ & 48 & 8.3 E-9 \\
\hline $1 / 7 / 14$ & 51 & 2.7 E-8 \\
\hline $4 / 8 / 14$ & 54 & 1.5 E-8 \\
\hline $7 / 8 / 14$ & 57 & 1.7 E-9 \\
\hline
\end{tabular}

\begin{tabular}{|l|l|l|}
\hline \multicolumn{3}{|l|}{ Test 34H (GLT-S), $300{ }^{\circ} \mathrm{F}$} \\
\hline No rad. & $\begin{array}{l}\text { Time at Temp } \\
\text { (months) }\end{array}$ & $\begin{array}{l}\text { Leak Rate (std } \\
\text { cc He/sec) }\end{array}$ \\
\hline Date & 21 & $<1.7$ E-8 \\
\hline $3 / 15 / 2011$ & 24 & $<1.4$ E-8 \\
\hline $6 / 8 / 2011$ & 27 & $<3.2$ E-8 \\
\hline $9 / 19 / 2011$ & 24 & $<3.0$ E-8 \\
\hline $12 / 28 / 2011$ & 30 & $<2.2$ E-8 \\
\hline $3 / 19 / 2012$ & 33 & $<1.4$ E-8 \\
\hline $7 / 11 / 2012$ & 36 & 8.0 E-9 \\
\hline $10 / 8 / 2012$ & 39 & 2.3 E-9 \\
\hline $3 / 5 / 2013$ & 42 & 5.5 E-9 \\
\hline $6 / 4 / 2013$ & 45 & 5.7 E-9 \\
\hline $9 / 4 / 13$ & 48 & 2.6 E-9 \\
\hline $12 / 3 / 13$ & 52 & 1.5 E-8 \\
\hline $3 / 10 / 14$ & 54 & 1.3 E-8 \\
\hline $6 / 10 / 14$ & 57 &
\end{tabular}


Table 5. Summary of compression set data* from O-ring fixtures

\begin{tabular}{|c|c|c|c|c|c|c|}
\hline Fixture ID \& History & $\begin{array}{l}\text { Time since } \\
\text { Opening }\end{array}$ & $\begin{array}{ll}\text { Comp. Set - } \\
\text { Inner / Outer } \\
\text { O-ring }\end{array}$ & $\begin{array}{l}\text { Time since } \\
\text { Opening }\end{array}$ & $\begin{array}{l}\text { Comp. Set - } \\
\text { Inner / Outer } \\
\text { O-ring }\end{array}$ & $\begin{array}{l}\text { Time } \\
\text { since } \\
\text { Opening }\end{array}$ & $\begin{array}{l}\text { Comp. Set - } \\
\text { Inner / Outer } \\
\text { O-ring }\end{array}$ \\
\hline \multicolumn{7}{|c|}{ GLT O-Ring Fixtures reported previously with high temperature leak test difficulties } \\
\hline 2 (392 days at $300^{\circ} \mathrm{F}$ ) & & & & & 30 days & $62 \% / 59 \%$ \\
\hline 29 (283 days at $200^{\circ} \mathrm{F}$ ) & & & & & 30 days & $30 \% / 18 \%$ \\
\hline 38 (473 days at $300^{\circ} \mathrm{F}$ ) & $<30$ min. & $85 \% / 87 \%$ & & & & \\
\hline 39 (456 days at $300^{\circ} \mathrm{F}$ ) & $<30$ min. & $77 \% / 81 \%$ & & & & \\
\hline 45 (291 days at $300^{\circ} \mathrm{F}$ ) & & & & & 30 days & $60 \% / 71 \%$ \\
\hline 46 (493 days at $300^{\circ} \mathrm{F}$ ) & $<30$ min. & $76 \% / 75 \%$ & & & & \\
\hline 47 (394 days at $\left.300^{\circ} \mathrm{F}\right)$ & 1 hour & $80 \% / 81 \%$ & 5 days & $77 \% / 73 \%$ & 34 days & $68 \% / 72 \%$ \\
\hline 48 (490 days at $\left.300^{\circ} \mathrm{F}\right)$ & $<30$ min. & $84 \% / 84 \%$ & & & & \\
\hline 50 (265 days at $300^{\circ} \mathrm{F}$ ) & & & & & 30 days & $42 \% / 38 \%$ \\
\hline 60 (454 days at $300^{\circ} \mathrm{F}$ ) & $<30$ min. & $88 \% / 89 \%$ & & & & \\
\hline 62 (282 days at $\left.300^{\circ} \mathrm{F}\right)$ & & & & & 30 days & $50 \% / 54 \%$ \\
\hline \multicolumn{7}{|c|}{ GLT O-Ring Fixtures removed after failing room temperature leak test } \\
\hline 8 (2082 days at $\left.300^{\circ} \mathrm{F}\right)$ & 15 minutes & $90 \% / 92 \%$ & 13 days & $94 \% / 91 \%$ & 30 days & $94 \% / 89 \%$ \\
\hline 12 (1020 days at $\left.300^{\circ} \mathrm{F}\right)$ & 7 minutes & $82 \% / 70 \%$ & 14 days & $75 \% / 55 \%$ & 30 days & $74 \% / 49 \%$ \\
\hline 14D (45 days at $\left.400^{\circ} \mathrm{F}\right)$ & 21 minutes & $51 \% / 77 \%$ & 9 days & $54 \% / 74 \%$ & 85 days & $45 \% / 66 \%$ \\
\hline $18 \mathrm{D}\left(497\right.$ days at $\left.350^{\circ} \mathrm{F}\right)$ & 23 minutes & $91 \% / 96 \%$ & 14 days & $93 \% / 97 \%$ & 30 days & $92 \% / 97 \%$ \\
\hline 19D (594 days at $\left.350^{\circ} \mathrm{F}\right)$ & 13 minutes & $95 \% / 94 \%$ & 14 days & $98 \% / 98 \%$ & 30 days & $97 \% / 97 \%$ \\
\hline 21D (27 days at $400^{\circ} \mathrm{F}$ ) & 27 minutes & $66 \% / 77 \%$ & 9 days & $58 \% / 69 \%$ & 80 days & $53 \% / 66 \%$ \\
\hline 23D (12 days at $\left.450^{\circ} \mathrm{F}\right)$ & 21 minutes & $65 \% / 70 \%$ & 14 days & $53 \% / 63 \%$ & 90 days & $54 \% / 59 \%$ \\
\hline 26 (1410 days at $\left.300^{\circ} \mathrm{F}\right)$ & 10 minutes & $90 \% / 91 \%$ & 14 days & $88 \% / 89 \%$ & 30 days & $88 \% / 88 \%$ \\
\hline $31\left(1292\right.$ days at $\left.300^{\circ} \mathrm{F}\right)$ & 15 minutes & $84 \% / 78 \%$ & 14 days & $80 \% / 67 \%$ & 31 days & $78 \% / 65 \%$ \\
\hline 32 (1352 days at $\left.300^{\circ} \mathrm{F}\right)$ & 14 minutes & $93 \% / 83 \%$ & 14 days & $90 \% / 73 \%$ & 31 days & $89 \% / 71 \%$ \\
\hline $49\left(1360\right.$ days at $\left.300^{\circ} \mathrm{F}\right)$ & 14 minutes & $84 \% / 81 \%$ & 14 days & $82 \% / 80 \%$ & 30 days & $81 \% / 79 \%$ \\
\hline $33\left(1979\right.$ days at $\left.300^{\circ} \mathrm{F}\right)$ & 10 minutes & $88 \%$ / 82\% & 12 days & $84 \% / 74 \%$ & 29 days & $84 \% / 73 \%$ \\
\hline \multicolumn{7}{|c|}{ GLT O-Ring Fixtures removed for other reasons } \\
\hline 28 (630 days at $\left.200^{\circ} \mathrm{F}\right)$ & 4 hours & $68 \% / 62 \%$ & 10 days & $31 \% / 28 \%$ & 230 days & $28 \% / 24 \%$ \\
\hline $\begin{array}{l}62-2007 \text { ( 6 months } \\
\left.\text { at } 300^{\circ} \mathrm{F}\right)\end{array}$ & 4 hours & $66 \% / 77 \%$ & 11 days & $35 \% / 35 \%$ & 230 days & $32 \% / 31 \%$ \\
\hline $7\left(2167\right.$ days at $\left.300^{\circ} \mathrm{F}\right)$ & 19 minutes & $93 \% / 84 \%$ & 12 days & $90 \% / 78 \%$ & 29 days & $90 \% / 75 \%$ \\
\hline 30 (1902 days at $\left.300^{\circ} \mathrm{F}\right)$ & 16 minutes & $94 \% / 82 \%$ & 12 days & $90 \% / 73 \%$ & 29 days & $89 \% / 71 \%$ \\
\hline $52\left(1848\right.$ days at $\left.300^{\circ} \mathrm{F}\right)$ & 12 minutes & $92 \% / 87 \%$ & 12 days & $90 \% / 80 \%$ & 29 days & $88 \% / 79 \%$ \\
\hline \multicolumn{7}{|c|}{ GLT-S O-Ring Fixtures removed after failing room temperature leak test } \\
\hline $28 \mathrm{H}\left(50\right.$ days at $\left.400^{\circ} \mathrm{F}\right)$ & 10 minutes & $84 \% / 91 \%$ & 11 days & $80 \% / 88 \%$ & 26 days & $80 \% / 88 \%$ \\
\hline $38 \mathrm{H}\left(358\right.$ days at $\left.350^{\circ} \mathrm{F}\right)$ & 20 minutes & $92 \% / 92 \%$ & 14 days & $90 \% / 88 \%$ & 30 days & $88 \% / 87 \%$ \\
\hline $39 \mathrm{H}\left(114\right.$ days at $\left.350^{\circ} \mathrm{F}\right)$ & 15 minutes & $78 \% / 90 \%$ & 11 days & $74 \% / 89 \%$ & 26 days & $72 \% / 88 \%$ \\
\hline $45 \mathrm{H}\left(99\right.$ days at $\left.400^{\circ} \mathrm{F}\right)$ & 12 minutes & $93 \% / 93 \%$ & 11 days & $91 \% / 92 \%$ & 26 days & $91 \% / 91 \%$ \\
\hline $50 \mathrm{H}\left(281\right.$ days at $\left.400^{\circ} \mathrm{F}\right)$ & 14 minutes & $95 \% / 82 \%$ & 14 days & $93 \% / 76 \%$ & 30 days & $93 \% / 76 \%$ \\
\hline $58 \mathrm{H}\left(75\right.$ days at $\left.400^{\circ} \mathrm{F}\right)$ & 10 minutes & $83 \% / 87 \%$ & 11 days & $81 \% / 84 \%$ & 26 days & $78 \% / 84 \%$ \\
\hline $60 \mathrm{H}\left(50\right.$ days at $\left.400^{\circ} \mathrm{F}\right)$ & 7 minutes & $84 \% / 93 \%$ & 11 days & $80 \% / 90 \%$ & 26 days & $79 \% / 89 \%$ \\
\hline $62 \mathrm{H}\left(50\right.$ days at $\left.400^{\circ} \mathrm{F}\right)$ & 7 minutes & $89 \% / 91 \%$ & 11 days & $86 \% / 89 \%$ & 26 days & $85 \% / 89 \%$ \\
\hline
\end{tabular}

* Compression set is calculated per ASTM D395, Method B, as follows:

comp. set $(\%)=\left(t_{i}-t_{f}\right) /\left(t_{i}-\right.$ groove depth $) * 100$

If the initial radial thickness was not recorded, 0.139 inch is assumed. 


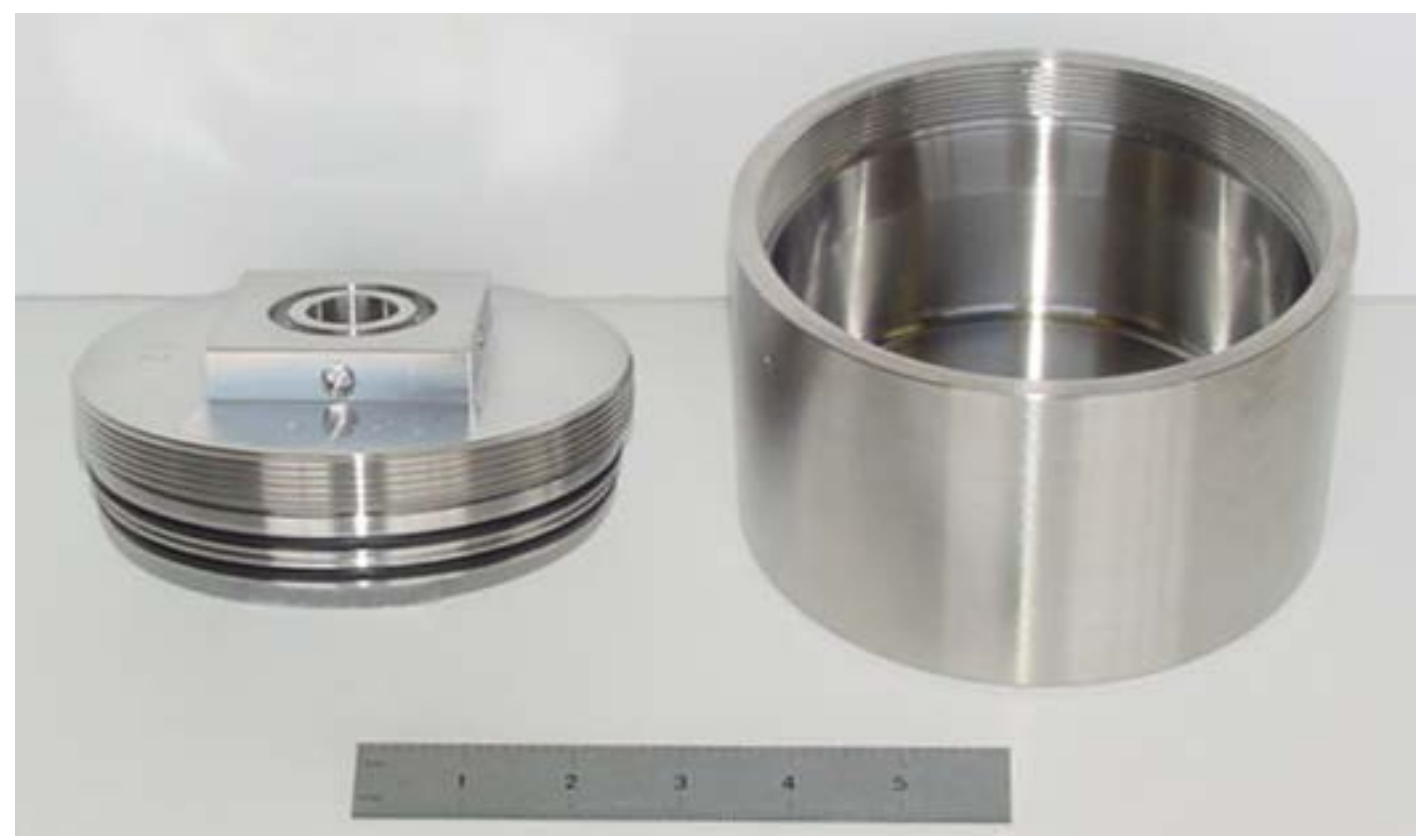

Figure 1. Mock-up PCV test fixture lid and body.

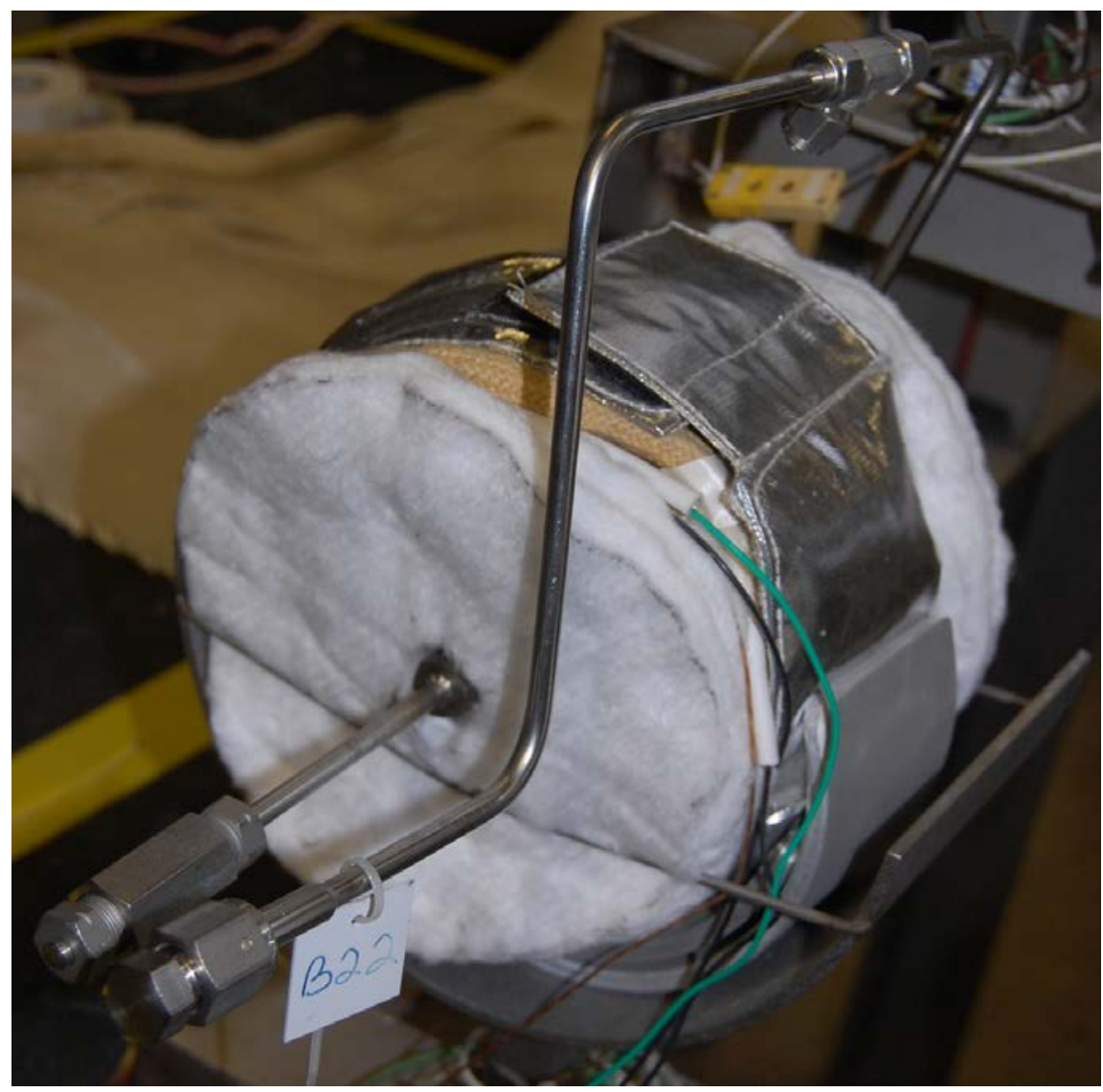

Figure 2. Assembled mock-up PCV. 


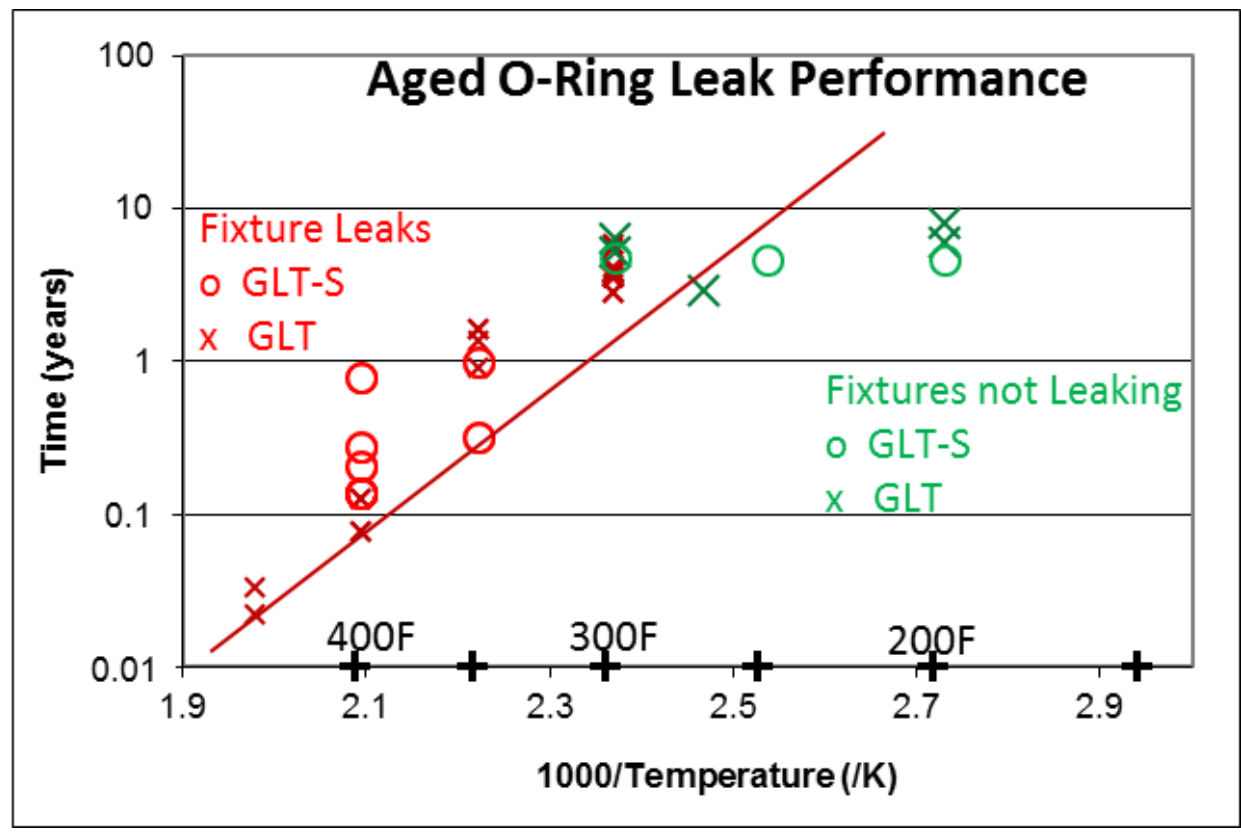

Figure 3. Summary of behavior for fixtures that failed the room temperature leak test and for fixtures still in test. The trend line illustrates a lower bound projection. 
CC: G. A. Abramczyk, 730-A

J. S. Bellamy, 730-A

G. T. Chandler, 773-A

W. L. Daugherty, 773-A

K. A. Dunn, 773-41A

B. A. Eberhard, 105-K

T. W. Griffin, 705-K

E. R. Hackney, 705-K

D. R. Leduc, 730-A

J. W. McEvoy, 707-C

T. E. Skidmore, 730-A

K. E. Zeigler, 773-41A

Document Control 